\title{
Zrozumieć Zagładę. Społeczna psychologia Holokaustu, red. Leonard S. Newman, Ralph Erber, tłum. M. Budziszewska, A. Czarna, E. Dryll, A. Wójcik, PWN, Warszawa 2009
}

Najwartościowsze z reguły okazują się te tomy zbiorowe, które tworzą starannie zaplanowaną i spójną kompozycję, stanowiącą całość myślową. Rola redaktorów w tego typu publikacjach polega na odpowiednim dobraniu autorów i zagadnień. Rzadko udaje się to w przypadku tzw. materiałów pokonferencyjnych. Nie potrafię arbitralnie orzec, czy Zrozumieć Zagładę w opracowaniu Leonarda S. Newmana i Ralpha Erbera jest plonem wcześniejszego sympozjum. Wydaje się jednak, że zgromadzone w tej publikacji artykuły zostały zamówione na jej potrzeby.

Cel, jaki sobie stawiają badacze, nie jest nowy. Pytanie o racje stojące za postępowaniem nazistowskiego zbrodniarza musiało przecież zrodzić się już w umysłach osób, które w „epoce pieców” doznały krzywd od hitlerowców. Poniekąd jest to naturalny odruch u kogoś, kto próbuje pojąć własną sytuację i odpowiedzieć sobie na podstawową wątpliwość: dlaczego cierpię? Mimo iż cel nienowy, a pytanie być może nawet nieco banalne w swej bezpośredniości i prostolinijności, odpowiedź nie jest łatwa. Choć z czasem, jako filozofowie, socjologowie, teologowie, literaturoznawcy, poszerzamy pole refleksji, a ją samą wysubtelniamy, nie mamy żadnej pewności, że jesteśmy dziś bliżsi sedna sprawy niż ci, którzy zagadnienie to podnosili kilkadziesiąt czy nawet kilkaset lat wcześniej (bo przecież nie dotyczy ono tylko kwestii Holokaustu).

Przywołując klasyczne rozróżnienie Raula Hilberga na sprawców, ofiary i świadków, często pomijamy tę ostatnią grupę, traktując ją jako nic niewnoszącą do namysłu nad etiologią zła. Przyjmujemy bowiem odruchowo, że nie zachodzi żaden konieczny związek między postępowaniem sprawcy a reakcjami świadków. Tymczasem do najbardziej przerażających odkryć psychologii społecznej należy to, iż świadkowie odegrali niebagatelną rolę w utwierdzaniu się oprawcy co do słuszności obranej przez siebie ścieżki zbrodni. Ściślej mówiąc, odnotowana zależność nie jest prosta i bezpośrednia. Opiera się ona na sferze niedopowiedzeń, przemilczeń. Idzie o opisany jakiś czas temu przez badaczy mechanizm samooszukiwania się (Sprawcy bez wyrzutów sumienia Ralpha Erbera). Długo przyjmowano za pewnik, że wypowiedzi katów, w których stanowczo przekonywali oni o swej niewinności, są dowodem patologicznego zwyrodnienia, niewymagającym komentarza przejawem ich deprawacji (co poniekąd kryło w sobie aspekt pocieszający - my tacy nie jesteśmy). To jednak, co miało być argumentem przemawiającym za cynizmem prześladowców, okazało się zjawiskiem bardziej skomplikowanym. Oto bowiem konformizm obserwatorów, osób niezaangażowanych bezpośrednio w zbrodnie i pogromy, objawił się nam jako ważny stymulator w procesie przejścia zwykłego 
człowieka do roli „gorliwego kata” (wedle znanej formuły Daniela Goldhagena). Nie napotykając sprzeciwu ze strony obserwatorów, sprawca żył w przeświadczeniu o słuszności dokonanego wyboru (Psychologia świadków, sprawców i ratujacych bohaterów Ervina Stauba).

Kat dochodził do wniosku, że uczestniczy w czymś innym niż zabijanie. Niektórzy z nazistów byli wręcz przeświadczeni - zgodnie z duchem słynnego przemówienia Heinricha Himmlera w Poznaniu do wyższych rangą dowódców SS - że realizują wielkie dzieło zbawiania świata. Swój udział w tym przedsięwzięciu pojmowali jako ciężką i niemiłą służbę, chętnie jednak ponosili wszelkie wyrzeczenia w imię świetlanej przyszłości, a piętrzące się trudności wzmagały jedynie ich żarliwość. Powstawał samonapędzający się mechanizm, którego nawet klęska III Rzeszy nie była w stanie zdemontować. Tym samym jakby na nowo odkrywamy rangę czynnika ideologicznego, który po ukazaniu się książki Hannah Arendt Eichmann $w$ Jerozolimie trochę przybladł, skonfrontowany z wizją „mordercy zza biurka”. Uwagi Arendt wsparł eksperyment Stanleya Milgrama dotyczący granic respektu wobec władzy i przełożonych (Zachowanie sprawców jako destrukcyjne postuszeństwo Thomasa Blassa).

Ideologicznie zacietrzewienie, granicząca $\mathrm{z}$ opętaniem obsesja, jawi się jako nader doniosły element rzutujący na decyzje zbrodniarzy. Każe to zmodyfikować nasze dotychczasowe spojrzenie na aspekt ekonomiczny Holokaustu podnoszony już w Medalionach Zofii Nałkowskiej czy w opowiadaniach obozowych Tadeusza Borowskiego. Zysk, jaki czerpano ze zbrodni, był skutkiem ubocznym. I jakkolwiek był ważny, trudny do zbagatelizowania, stanowił zazwyczaj pochodną zmiennych ideologicznych. Mord na Żydach dokonał się nie dlatego, że mieli oni pieniądze (choć zapewne brano to pod uwagę, jako dodatkową „wartość” Endlösung), ale dlatego, że w kulturze europejskiej byli oni od wieków grupą napiętnowaną, obarczoną przesądami i stereotypami. Nie jest więc sprawą przypadku, że to właśnie Żydzi - pogardzani i posądzani o najróżniejsze bezeceństwa - zostali wybrani przez Hitlera i jego popleczników na ofiary (Jagnięta ofiarne w wilczym przebraniu Petera Glicka). To im - wzorem wieków wcześniejszych - najłatwiej było przypisać winę za klęskę w I wojnie światowej, chaos i kryzys gospodarczy, zagrożenie komunistyczne. Nie da się zatem wszystkiego wyjaśnić względami ekonomicznymi, ale też i wymiar ideologiczny Szoa nie może być traktowany jako klucz do każdych drzwi.

Tym samym dotykamy zagadnienia szerszego i zarazem fundamentalnego w namyśle nad Zagładą. Trzeba się zgodzić, po pierwsze, iż Holokaust stanowił zbiór różnych czynników, składową przyczyn odmiennego autoramentu. Po drugie, w laboratoriach naukowych nigdy nie uda nam się precyzyjnie odtworzyć warunków, w jakich działał oprawca, tak by uwzględnić wszystkie powody zewnętrzne i wewnętrzne, które kształtowały sferę jego decyzji. Postępowanie badawcze prowadzi nieuchronnie - do wyabstrahowania jednego (niekiedy kilku) czynników i oglądania przez ten pryzmat całości. Być może źródła zła - a co za tym idzie, zawiłości naszej natury - należą do kręgu tych zjawisk, co do których nigdy nie będziemy 
mieli ostatecznej pewności. Jeśli bowiem odłożyć na bok eksplikacje genetyczne (do czego namawia Zoomorfizm ludzkiej zbiorowej przemocy Roberta B. Zajonca), przestać bić pokłony przed genetyką jako nauką zdolną wytłumaczyć nam wszystko, co wiąże się z naszym zachowaniem, to chyba warto zastanowić się nad tym, czy nie trzeba (z konieczności) zostawić nieco miejsca na tajemnicę, choćby maleńki obszar, który pozostanie domeną domysłu, a nie pewności. Wiele bowiem przemawia za tym, iż metodami naukowymi nie da się rozwikłać zagadki zła. Niewykluczone, że to sztuka (choćby porażające malarstwo Francisa Bacona) ma w tej materii więcej do powiedzenia niż rzeczywistość laboratoriów. Tu jednak pojawiają się kolejne znaki zapytania, gdyż wchodząc na teren sztuki, często musimy się poruszać w horyzoncie tego, co oferuje intuicja i nieweryfikowalne na mocy procedur naukowych tezy.

Fundamentalny dla psychologii społecznej wpływ zmiennych zewnętrznych (sytuacji) na zachowanie jednostki (jednostek) nie może ostatecznie wyjaśnić przejawów ludzkiego okrucieństwa, tak jak nie wyjaśnia bohaterstwa. Musimy zgodzić się, że niepodobna dociec i arbitralnie ustalić, dlaczego jedni pomagali, a inni uczestniczyli w zbrodni. Psychologia społeczna udzieli odpowiedzi jedynie cząstkowej. Nie będzie ona mniej ciekawa czy możliwa do zignorowania, ale zawsze cząstkowa. Gdy idzie o motywy kierujące osobami, które ratowały Żydów, zazwyczaj podaje się względy światopoglądowe (np. nakazy religijne), związki uczuciowe świadków z prześladowanymi, wychowanie w duchu poszanowania dla drugiego człowieka, które pomija wszelkie klasyfikacje narodowościowe, religijne, ideologiczne, a skupia się na tym, co wspólne dla rodzaju ludzkiego. Niekiedy przywołuje się odwagę, brawurę i pewien typ osobowości, dla której niebezpieczeństwo jest naturalnym żywiołem. Przy okazji zbrodniarzy - oprócz wymienionych już czynników - najczęściej mówi się o osobowości autorytarnej (Autorytaryzm $i$ Holokaust Petera Suedfelda i Marka Schallera), znaczeniu wychowania w ideologii nacjonalistycznej, konformizmie, agresji wzbudzanej przez trudne warunki ekonomiczne, resentymencie.

Do najbardziej intrygujących i niepokojących należy pytanie o to, jak oprawcom udawało się wyjść ze swej roli i wejść w inne, te, które wyznaczało im społeczeństwo - dobrego i troskliwego ojca, męża, sąsiada, chrześcijanina. Często powraca do mnie fragment z Czekając na barbarzyńców Johna Maxwella Coetzee, kiedy ofiara indaguje swego prześladowcę: „Czy łatwo panu przychodzi zasiąść potem do posiłku? Wyobrażam sobie, że odczuwa się potrzebę mycia rąk. Ale tu nie wystarcza żadne zwykłe mycie, wymaga to chyba posługi kapłańskiej, rytuału oczyszczenia, nie sądzi pan? Czegoś w rodzaju spowiedzi i pokuty dla zmazania grzechów - w ten sposób to sobie wyobrażam. W przeciwnym razie, czy możliwy byłby powrót do normalnego życia, do codzienności - na przykład, czy można bez tego usiąść przy stole i dzielić chleb z rodziną czy kolegami?". Do najstraszliwszych lekcji, których udziela nam psychologia społeczna, należy wiedza o stawaniu się zbrodniarzem. Okazuje się, że istnieje coś takiego, jak nauka zbrodni. To oznacza, iż zbrodniarzami się stajemy; zasmakowujemy w zbrodni jak w przyjemności. To, co za pierw- 
szym razem zdaje się nam odrażające i co sprawia, że z obrzydzeniem myślimy o sobie, odczuwamy do siebie wstręt, któremu towarzyszą wyrzuty sumienia, z czasem odchodzi w niepamięć, eliminuje poczucie winy, wiedzie nas ścieżką do zupełnego zobojętnienia, mechanicznego wykonywania zleconych czynności.

Bywało nawet, że kat zaczynał odczuwać zadowolenie ze swej „pracy”. W ostatnich latach nazbyt umniejszano - tak jak początkowo demonizowano - sadyzm. Kontrowersyjna w kilku punktach rozprawa Goldhagena Gorliwi kaci Hitlera (zobacz polemikę w niniejszym tomie Czym jest „socjopsychologiczne” wyjaśnienie zachowania sprawcy? Leonarda S. Newmana) przywraca ten problem, ponownie ujawniając jego relatywnie duży zasięg. O ile zatem prawdą jest słynne stwierdzenie Zygmunta Baumana z Nowoczesności i Zagłady, że w każdym z nas drzemie „mały esesman”, o tyle może prawdziwe jest także przeświadczenie Emila Ciorana o tym, iż zło stanowi niezbywalny, niemożliwy do usunięcia fragment nas samych. Gdyby iść dalej tym tropem, wypadałoby przyjąć, że jest ono jakimś rodzajem ciemnej substancji zalegającej głęboko w pokładach psychiki ludzkiej. Czyż bowiem psychopatologia nazistowskiego zbrodniarza nie zmusza nas do ponownego pochylenia się nad demonizmem zła, który - chyba zbyt pochopnie - wymazaliśmy ze świadomości społecznej? Trudno zaprzeczyć, że w pierwszym odruchu jesteśmy skłonni reagować na okrucieństwa esesmanów w Auschwitz podobnie jak Zofia Kossak we wspomnieniach obozowych pt. $Z$ otchłani. Zdaje się nam, że mamy do czynienia z jakimś rodzajem zła nie-ludzkiego, przekraczającego nasze zdolności pojmowania.

Autorzy tekstów zebranych w tomie pod redakcją Newmana i Erbera nie są ani pierwszymi, ani ostatnimi, którzy stają przed dylematem, czy ich próba wyjaśnienia zjawiska nie zostanie przez niektórych czytelników odebrana jako chęć usprawiedliwienia sprawców. Zrozumieć bowiem - nie tylko w powszechnej świadomości - oznacza wybaczyć, a przynajmniej wykonać duży krok w tę stronę. To jeden z problemów, których nie da się jednoznacznie rozstrzygnąć. Zawsze istnieć będzie obawa, że prace typu Wyjaśnianie Hitlera Rona Rosenbauma, Lekcje ciemności Dariusza Czai czy Zrozumieć Zagładę - mimo deklaracji badaczy - przyniosą skutek odwrotny od zakładanego. W odpowiedzi pozostaje nam tylko przytoczyć przedostatnie zdanie z „Epilogu”: „Jeśli ta książka sprawi, że ludzie będą bardziej świadomi tego, jakie sytuacje społeczne mogą doprowadzić ich do stania się uczestnikami zbiorowego mordu, i dzięki temu stworzy przynajmniej maleńki wkład w zapobieganie podobnym zbrodniom, to będzie warto. Można śmiało powiedzieć, że wszyscy autorzy tej książki przygotowali ją z nadzieją na życie w świecie, gdzie wolno otwarcie dyskutować nawet o możliwości wybaczenia”. 